\title{
BRAZILIAN LEARNERS OF ENGLISH PERCEPTIONS ABOUT ORAL PRODUCTION ON A DIGITAL STORYTELLING TASK CYCLE
}

\author{
PERCEPÇÕES DE APRENDIZES BRASILEIROS DE INGLÊS SOBRE SUA \\ PRODUÇÃ̃O ORAL EM HISTÓRIAS DIGITAIS NUM CICLO DE TAREFAS \\ Fernanda Delatorre $^{1}$, Juliane Regina Trevisol $^{2}$
}

\begin{abstract}
This study investigated Brazilian learners of English perceptions about their production in a digital storytelling task cycle. Participants were 14 learners of English from an undergraduate program in Brazil. Data from the present study were obtained from participants' answers to the four questionnaires presented to them along the digital storytelling task cycle. After that, their answers were grouped and analyzed in order to have a broad view on their perceptions regarding oral production in the digital storytelling task cycle. The present study found that participants were concerned about their oral production as a whole, that they became more engaged and critical regarding the language learning process and aware of it with the use of digital storytelling. It also found that the teacher should be prepared to use technology and tasks in class and stimulate their students to use them so that language learning may be improved from its use.
\end{abstract}

KEYWORDS: oral production, digital storytelling, task, Brazilian learners of English

RESUMO: Este estudo investigou as percepções de estudantes brasileiros de inglês sobre sua produção oral num ciclo de tarefas digitais. Participantes foram 14 brasileiros graduandos de Letras Inglês. Os dados para o presente estudo foram coletados a partir das respostas dos participantes a quatro questionários respondidos ao longo do ciclo de tarefas de histórias digitais, as quais foram agrupadas e analisadas a fim de se ter uma visão geral sobre suas percepções relacionadas à produção oral no ciclo de tarefas de histórias digitais. O presente estudo demonstrou que os participantes estavam conscientes do processo de aprendizagem como um todo, que eles se tornaram mais críticos e engajados em relação a ele e ao uso de tecnologia e histórias digitais neste processo. Este estudo também observou que os professores deveriam estar preparados para usar tecnologia e tarefas para estimular seus alunos a usá-las a fim de melhorar sua aprendizagem da língua a partir disso.

PALAVRAS-CHAVE: produção oral, histórias digitais, tarefas, aprendizes brasileiros de inglês

\section{Introduction}

According to Ellis (2003), the overall goal of any language learner is to be able to use the target language in an accurate, fluent and context-appropriate manner. However, as claimed by Trevisol (2019), being able to develop such communicative skills fully has been a challenging

\footnotetext{
${ }^{1}$ Doutora em Estudos da Linguagem pelo Programa de Pós-Graduação em Inglês: Estudos Linguísticos e Literários (PPGI) da Universidade Federal de Santa Catarina (UFSC)

${ }^{2}$ Doutora em Letras - Inglês pela Universidade Federal de Santa Catarina (UFSC)
} 
endeavor for several learners despite teachers' efforts to compartmentalize time in order to provide enough opportunities for learners to develop listening, reading, writing and speaking skills, vocabulary, intercultural awareness, among other important elements, in a successful way in the classroom, for instance. In addition, Appel and Borges (2011) consider that besides being complex, time devoted to second language (L2) oral production in class seems not to be enough for learners to improve it, especially in contexts such as the Brazilian one with heterogeneous groups in class, as observed by Bergsleithner (2009).

However, Shorna and Shorna (2019) point out that teaching and learning in class can be more 'enjoyable' (p. 17) with the use of technology, such as smartphones and apps, or with some social networking sites, such as Facebook, WhatsApp, Messenger, as suggested by Namaziandost, Nasri and Keshmirshekan (2019) and Paiva (2019). Moreover, to Namaziandost, Nasri and Keshmirshekan (2019), internet can contribute to develop learners' reading, writing, speaking and listening skills. Opportunities for L2 oral production, its practice and enhancement in the classroom should then be provided, and one way it could be achieved is with the use of tasks and digital technology.

Having said that, the aim of this study was to investigate the perceptions of Brazilian learners of English regarding their oral production ${ }^{3}$ in a digital storytelling task cycle in English conducted via WhatsApp. Therefore, Section 2 will present the main concepts and the more relevant literature for this study; Section 3 will present the participants and describe the method for data collection and analysis; Section 4 will present and discuss the results and, finally, Section 5 will present the conclusion of the study.

\section{Review of literature}

A task is generally understood as "an activity that requires learners to use language, with emphasis on meaning, to attain an objective" (BYGATE; SKEHAN; SWAIN, 2001, p. 11). In addition, as pointed out by Ellis (2003), leaners may use whatever linguistic resources they have available in order to achieve this goal of accomplishing the task - which may also involve any skill such as reading, writing, listening, or speaking — producing language pragmatically but keeping the focus on meaning. Moreover, the task-based approach is learner-centered, which means the learner is the main protagonist in class, the one who 'learns by doing', who actively

\footnotetext{
${ }^{3}$ Following D'Ely (2006) and Weissheimer (2007), speaking, speech production or oral production refer to the ability to perform orally in an L2, which sometimes are used interchangeably.
} 
engages in the activities proposed to reach a given outcome. Tasks performed in class should resemble the real world (the one outside of class). And in an era where digital technology has been rapidly evolving, 'new tasks' may arise (GONZÁLEZ-LLORET; ORTEGA, 2014), requiring us to answer emails, book flights and select hotels that best fit our budgets using our smartphones apps, for instance, among others (Santos, Trevisol \& Delatorre, in press).

As summarized in Trevisol (2019), tasks have been investigated since the 1980's under different perspectives, such as cognitive and sociocultural, attending to a variety of task-related elements as pre-task planning, task repetition, post-task effects, in contexts such as face-to-face, hybrid or virtual classrooms, investigating how language skills, including L2 oral production, may be developed through web-conferencing or Skype sessions with certain technological resources as tablets. In this regard, L2 teaching and learning have made use of some communication devices (e.g., chats, forums and videoconferences), integrating and enhancing the four skills — speaking, listening, reading and writing — in a more meaningful and authentic manner language use, as suggested by Tumolo (2006; 2015; 2017). Furthermore, Braga, Gomes Junior and Racilan (2017) and Shorna and Shorna (2019) acknowledge that mobile learning with smartphones, for instance, can be more contextualized and meaningful for learners to improve their language skills.

Another point raised by Namaziandost, Nasri and Keshmirshekan (2019) regarding the use of technology and social media in language teaching and learning is that this type of learning is more student-centered since learners can express themselves with no shame even when they are not completely sure about their speech, share their productions with their colleagues and teachers, obtain some feedback from them and improve their oral (speaking) skills, consequently. Namaziandost, Nasri and Keshmirshekan (2019) also observe that this studentcentered learning methodology associated with technology and social media has the potential to give more room to oral speaking skill and listening aptitudes inside and outside the classroom. Moreover, Shorna and Shorna (2019) recommend that learners should be aware of the use, importance and benefits of technology in the foreign language learning.

Shorna and Shorna (2019) also found in their research that learners can be more motivated and reduce their affective filter with the use of smartphones and apps elevating their language competency. Braga, Gomes Junior and Racilan (2017) consider that this mobile learning can favor learning in formal and informal contexts, or inside and outside the classroom, engage teachers and learners in the learning process, integrate learners among themselves and with videos and texts to create new material in a more collaborative work. 
Namaziandost, Nasri and Keshmirshekan (2019) and Shorna and Shorna (2019) also drew attention to the teacher's role in this new learning process. Shorna and Shorna (2019) claim that teachers could create tasks that involve learners even when they are not in class, which could be achieved with the use of smartphones and apps, for instance, whereas Namaziandost, Nasri and Keshmirshekan (2019) consider that teachers could give their students some assignments that demand a more collaborative and group work that make students learn with their colleagues. As suggested by Braga, Gomes Junior and Racilan (2017), apps and other social network sites ${ }^{4}$ associated with specific tasks may help in the language learning process and contribute to its enhancement, development and effective language use.

One possibility for integrating technology into L2 classes is to combine it with careful task design and implementation by the teacher with digital storytelling that can be constructed by foreign language learners alone and/or in group in and also outside the class.

Digital Storytelling is a type of computer communication technology, massively employed and investigated in the field of Education, and nowadays in the field of L2 pedagogy. In general terms, digital storytelling refers to "the process of creating a short, emotional, and compelling story through the combination of different technological modes, such as images, music and sounds, video clips, text, and/or narration" (CHRISTIANSEN; KOELZER, 2016, p. 2). These resource combinations integrate all language skills in a multimodal manner when L2 learners orally narrate part of their own stories. Moreover, the digital storytelling as pedagogical tool has shown learning benefits for L2 writing because it leads to story construction, script writing, as well as to their teachers and colleagues' feedback (CASTAÑEDA, 2013; HERRERA-RAMIREZ, 2013, PARDO, 2014; RAHIMI; YADOLLAHI, 2017). In addition, Nishioka (2016) and Yuskel, Robin and McNeil (2011) consider that digital storytelling enhances learners' digital skills, critical thinking ${ }^{5}$ as well as interpersonal and collaborative skills.

\section{Method}

This section describes the participants as well as the instruments and procedures used in data collection and analysis.

\footnotetext{
${ }^{4}$ See a list of apps and social network sites to be used in foreign language teaching and learning in Paiva (2019).

${ }^{5}$ It is understood here as "an application of skills such as reasoning, evaluating or analyzing, to one's thinking, in the process of making judgments and solving problems" (DONG, 2015, p. 16).
} 


\subsection{Participants}

Participants of the present study were 14 Brazilian learners of English ${ }^{6}$, seven female and seven male, all native speakers of Brazilian Portuguese (BP) enrolled at the English Intermediate level I course (evening classes), from the English language Program (Letras Língua Inglesa e Literaturas) at a public university in the state of Bahia, whose ages ranged from 18 to 50 at the moment of data collection. According to their answers to the background questionnaire, they tended to feel shy and nervous when speaking English.

\subsection{Instruments and procedures for data collection and analysis}

Data for the present study were taken from Trevisol (2019), who analyzed the impact of the storytelling task cycle on the oral production of Brazilian undergraduate learners of English considering complexity, accuracy, fluency and adequacy measures. However, the analysis that is going to be provided here is not discussed in Trevisol's (2019) being thus a subsequent analysis since it came out after the conclusion of the study.

Participants had to perform a cycle of tasks in which they had to answer four different questionnaires and to record first the description of their journey as English learners in audio only and then in video. In the first moment of data collection, they had to fill in the consent form, answer the background questionnaire, then think about their journey as English learners in a 10 minute unguided planning task and audio-record it. After that, they answered a second questionnaire about their perceptions of the first audio-recording task. At the end of the task cycle, they answered the third questionnaire, focused on the final script writing and videorecording about their journey as English learners. In order to organize their stories into videos, the software Moviemaker was used. Finally, they answered a fourth questionnaire one month after the video recording and production. Audios and videos were recorded in English and sent to the researcher via Whatsapp, whereas the questionnaires were answered in BP via Google Forms. After gathering all these data, they were all orthographically transcribed ${ }^{7}$.

The questionnaires gathered information on participants' experiences as English learners and profiles, perceptions on the experience with digital storytelling construction, technology and

\footnotetext{
${ }^{6}$ They were the participants of Trevisol's (2019) study.

${ }^{7}$ See Trevisol (2019) for further information and to check the transcriptions.
} 
L2 oral production related to pronunciation, grammar, speaking, training, practice and repetition, listening and writing, besides listening to music, watching movies and series, playing videogames and attending regular classes.

Section 4 will present the results regarding the perceptions about their L2 speech production, after which some comments on the possible implications for English teaching and learning at undergraduate level will be made since learners of English at this level tend to become teachers of English in the Brazilian context.

\section{Results and Discussion}

As this study intends to discuss Brazilian learners of English perceptions about their oral production in English in a digital storytelling task-cycle, the present section displays the results obtained from the analysis of their answers to the questionnaires, as explained in Section 3.2. Thus, it will provide a brief overview of their answers to their background Questionnaire 1, followed by an overview on their answers to Questionnaires 2, 3 and 4.

Regarding their answers about oral production ${ }^{8}$ or any possible implication or relation to oral production in Questionnaire 1, when they answered the question explaining why they had decided to take the English language Program at university, they mainly answered that it was because they liked the English language, as well as the songs they listened to in English, or because they would like to be fluent and to communicate, that is, understand and be understood by other speakers of English. One of them said that it was because s/he would like to become a teacher of English. Still regarding the studying of English, when they were asked if they had studied English before attending university, all of them said yes and $81 \%$ of them said they study English outside the classroom.

In addition, they also answered what kind of learners they were. The majority of them said they were shy in class, afraid of speaking and making pronunciation errors. One of them said that despite being shy, s/he tried to pay attention to the teachers' articulation and pronunciation of words whereas another participant said that s/he was not shy in class and that errors were opportunities to learn more and improve.

Moreover, they were also asked about their learning process and the possible missing aspect that could make it more effective. Thus, they came up with different answers but most of them emphasized the oral aspect of the language — such as speaking, practicing and

\footnotetext{
${ }^{8}$ Other aspects that may have been investigated in the original study (Trevisol, 2019) will not be taken into account here.
} 
pronunciation - as missing aspects that could make the learning process more effective. One of them said that the learning development process had been relevant but that s/he had to practice more. In addition, another participant reported that more time and more resources could be used to improve learning. Still, another participant acknowledged that $\mathrm{s} / \mathrm{he}$ had to improve the four skills (listening, speaking, writing and reading), but specially speaking, to improve his/her learning process. Finally, one participant said that despite noticing improvements in terms of learning, his/her English would never sound as native, though s/he pointed out it is possible to find ways to improve it in class and outside the classroom context. When they answered what learning English meant to them, participants frequently answered that it is more than learning only one language: it is learning about different cultures, it means to communicate and be able to understand others. Besides, they were asked if they had checked any specific website to study English to which $68.80 \%$ of them answered they used online dictionaries, YouTube and tandem. Regarding dictionary use, one of the participants said that s/he used it to learn new vocabulary and its pronunciation.

When participants were asked if they felt comfortable speaking English, most of them affirmed that they did not feel comfortable speaking English because they did not consider themselves fluent in the language, or due to lack of a vast vocabulary; they also explained feeling uncomfortable because they could not express their thoughts in English as they do in BP or because they considered that they made pauses in speech or felt ridiculous when trying to pronounce some words.

In addition, they had to answer what they would do to overcome the problems in the skill they had more difficulty with. The vast majority of them said they would practice more the oral language whereas some of them said that they would improve vocabulary knowledge and pronunciation, as well as grammar, being more committed to the learning process in order to improve speaking, in addition to speaking English more frequently and for longer period of time. However, one of them said that the s/he had some problems with the listening skill since s/he did not practice it as frequently as speaking, reading and writing, whereas another participant reported that s/he had difficulty with the speaking skill due to lack of its practice in regular school. Finally, one of the participants also mentioned that s/he tended to sing English songs in the church, which was something that helped him/her to learn new vocabulary.

The presentation of the results continues with their answers to Questionnaires 2, 3 and 4. A brief overview on the number of instances in which they mentioned each aspect of the language learning process that may be related to their perceptions on their oral production in the 
digital storytelling task cycle is provided in Table 1.

Table 1: Instances in which participants mentioned aspects that may be related to their perceptions on their oral production in a storytelling task cycle

\begin{tabular}{|l|c|c|c|}
\hline \multicolumn{1}{|c|}{ Aspect } & Questionnaire 2 & Questionnaire 3 & Questionnaire 4 \\
\hline Pronunciation & 4 & 17 & 15 \\
\hline $\begin{array}{l}\text { Speaking fluency, language use, } \\
\text { communication }\end{array}$ & 22 & 8 & 20 \\
\hline $\begin{array}{l}\text { Vocabulary knowledge, sentence } \\
\text { construction }\end{array}$ & 9 & 2 & 2 \\
\hline Grammar & 2 & 1 & 4 \\
\hline Writing & 1 & 2 & 0 \\
\hline $\begin{array}{l}\text { Word repetition in the recordings, } \\
\text { training and practice }\end{array}$ & 1 & 3 & 6 \\
\hline $\begin{array}{l}\text { Music, films, clips, games and } \\
\text { videos }\end{array}$ & 0 & 0 & 3 \\
\hline Regular school & 1 & 0 & 0 \\
\hline Language school & 1 & 0 & 4 \\
\hline Development as English learners & 1 & 2 & 3 \\
\hline
\end{tabular}

Source: The authors

According to Table 1, participants of the study more frequently considered that pronunciation, speaking, fluency, language use, communication, vocabulary knowledge and sentence construction were related to their perceptions about their oral production in the digital storytelling task cycle whereas grammar, watching films, clips or videos and listening to music, attending both regular school and language school were less frequently related to their perceptions about it. Word repetition, training and practice with the oral language was more frequently mentioned in Questionnaire 4 when they had to evaluate the digital storytelling task cycle as whole, as Table 1 shows. Finally, one aspect to be considered, despite not being very frequent, is the observation they made about their development as English learners throughout the digital storytelling task cycle.

Considering Questionnaire 2, in which participants had to answer about their impressions of the audio-recording in the first task from the digital storytelling cycle, one of them said that it was difficult to speak in English because s/he had difficulty in constructing sentences. After that they were asked if they liked the experience of audio-recording a digital story about their 
journey as English learners to which they reported that it was a dynamic activity that did not require them to have a perfect speech and which also allowed them to think about their development as learners. Participants also called attention to the fact that this experience of audio-recording allowed them to think about their needs, language use and practice. In addition, they had to answer what they did in the period of 10 minutes that preceded the audio-recording. Two of the participants mentioned that they had to write the words in BP, translate them despite having doubts in word spelling, in addition to the difficulties they had when speaking and recording the sentences to tell the story.

Inquired how they felt after audio-recording the digital storytelling, participants reported they had a lot of difficulty with English due to frustration to speak the language and express themselves as they did in BP or due to grammar and/or pronunciation problems they noticed. Regarding the question of whether they faced any difficulty to tell the story, they reported that their difficulties were mainly related to speech production in English, sentence construction and vocabulary, even for those who had studied in a language school, which one participant attributed to lack of daily language training. Moreover, when asked to comment on their speech, participants reinforced they had difficulty with speech production, vocabulary and pronunciation, besides some grammatical errors and language use problems. Furthermore, they were asked what they would change in their recordings and they frequently reported they would improve speaking, vocabulary knowledge and pronunciation, in addition to training the audiorecording if they had a chance to redo it.

After producing the script for the storytelling to record the video, they answered to Questionnaire 3. In this questionnaire they were first asked if they had had any difficulty at that point. Most of them reported issues with pronunciation of words when speaking and avoidance of pauses productions during the reading for the recording, which made them feel quite frustrated with their own speech. In addition, they were asked if they were concerned about their pronunciation during any moment of the recording: they affirmatively answered explaining their main concern about it was that they wanted to sound clear, or have a clear speech, and they had to repeat the script recording some times to avoid pronunciation problems and consult a translator in order to be clear and understood by their listeners. In addition to possible pronunciation matters, they were asked if grammar was an issue of concern while recording the script. They replied stating they were indeed concerned about grammatical errors and they tried to avoid them by seeking the help of classmates or the professor to check grammar, which suggested that receiving feedback was important to them, since they considered that adequate 
grammar in the script as well as clear pronunciation would make their speech clearer, or more comprehensible to the listeners (their colleagues).

Furthermore, participants were asked if they liked taking part in the digital storytelling task cycle and if they had learned something from this project. They answered that the digital storytelling-task cycle allowed them to think about their learning process, solving some doubts and mistakes they noticed having made during the process, especially regarding to speaking, pronunciation and writing. Thus, they affirmed that they learned more about pronunciation, grammar and vocabulary, which could be enhanced with more commitment to their own learning process. In addition, they had to answer which were the positive aspects of the digital storytelling-task cycle. Regarding that, they observed that it helped improving pronunciation due to the number of repetitions they had (when recording the audio for the video), grammar, speaking, writing, sentence construction in order to be understood, as well as the possibility of evaluating their own speech production, which was something they had been barely invited to do in a more systematized manner.

Finally, by answering Questionnaire 4 after closing the task cycle, that is, one month after the video presentation to the group, they were asked to reflect about their experience with digital storytelling. One participant explained that it was hard to accomplish the task but also very interesting because it allowed him/her to critically think about speaking and train pronunciation, besides learning new vocabulary. Another participant considered that s/he could practice the language whereas still another observed that the task allowed him/her to notice errors that $\mathrm{s} / \mathrm{he}$ was not used to noticing before. In addition, participants observed that their choices intended to keep their story as clear as possible for the listener, and that, on the other hand, their difficulty with pronunciation and/or to speak in English during the digital storytelling construction required some training and repeating the audio-recordings. This perception of errors (or focus on form) observed when repeating their audios is known to be quite important for fostering L2 restructuring and development and it has been triggered here by learners themselves while engaged in accomplishing the task. Several researchers have perceived the potential of such opportunities for L2 learning (e.g., SWAIN, 1995), especially with tasks that require learners to repeat performance (as in the audio-recording for the video) and when they have to display it publicly to an audience (BYGATE, 2001).

Participants also reinforced that the digital storytelling construction allowed them to think about their pronunciation - due to the repeated recordings and trainings to record the video - and to revise grammar and speech production in general. One of them pointed out it 
allowed him/her to see the importance of some grammatical rules — to better understand the whole text - as well as training pronunciation, which made s/he reflect that a certain level of commitment is necessary for language learning to be successful, and motivation, which was observed as a generally missing element during regular school.

Regarding what participants liked most in their digital story, the majority emphasized it was the portrayal of their first contact with English, which took place mainly with music and videos, besides classes at regular school. However, one of the participants said s/he could not tell exactly what s/he liked because, according to the participant, his/her limited knowledge in the language did not allow him/her to do it.

During the digital story construction process, participants asked their classmates and professor for help when needed, mainly to solve doubts about language (e.g., grammar, pronunciation) or about the storytelling construction (e.g., what to include in the video, the soundtrack, and photos). After finishing their video-stories, and showing them to their classmates, they were asked what they had indeed considered about their classmates' advice on their stories to which they reported that they mainly tried to sound more natural, paying more attention to their speech and pronunciation, as suggested by colleagues. Other positive aspects raised regarding the task project were the opportunity they had to speak and practice English (in a dynamic and motivational way - for the majority, it was the first time they were attempting to create a digital story) and remember some grammatical rules. At the end of the fourth questionnaire, they were invited to make any comment they wished. One of the learners said that to participate in this project was a great experience that helped him/her to improve pronunciation of some words s/he was in doubt; another said that s/he was very excited when realizing s/he could write in English using the dictionary only (without Google translator), which the participant considered a progress in his/her learning process.

In sum, their answers to the four questionnaires, as well as the summary provided in Table 1, demonstrate that participants frequently considered speaking, speech production, pronunciation, training and oral language practice as elements of relevance/concern, as well as grammar, vocabulary knowledge and sentence construction in relation to their oral performance in the digital storytelling task. In addition, according to their answers, they felt uncomfortable and shy when speaking English or even frustrated with their pronunciation in class, especially because their intentions were always to be as clear as possible to listeners in their digital story recordings, as well as more committed to their own learning process. Thus, their answers demonstrate that the digital storytelling task cycle can make them critically think about their 
own learning, looking for some solutions to solve problems faced, noticing mistakes in their own speech as they pay close attention to it, improving productions as they do and re-do the task, and developing overall awareness about oral language and what they do know now (e.g., vocabulary, pronunciation) and must still work on to develop, for instance. These results are in accordance with Nishioka's (2016), Tumolo's (2006, 2015, 2017) and Yuskel, Robin and McNeil's (2011) suggestions to use digital storytelling as a tool to achieve these improvements and awareness raising in the language learning process of the four skills (e.g., reading, writing, listening and speaking) and to Namaziandost, Nasri and Keshmirshekan's (2019) and Shorna and Shorna's (2019) to make learners more motivated, engaged and autonomous in a more collaborative learning of listening and speaking. Moreover, these results are also related to language learning viewed as a whole process (SCHAEFER; SALBEGO; LORENSET, 2019) and claimed by the Dynamic System Theory9 (DE BOT; LOWIE; VERSPOOR, 2007; ELLIS, 2007; LARSENFREEMAN, 1997).

Considering participants' answers to technology use and access to the internet in and outside the class to achieve the main task — create a personal digital story —, the development of the task cycle might be considered as a strategy to enhance learners' contact with oral English, as well as the other skills in an integrated manner, since they could consult online dictionaries to check for word meaning and pronunciation, as mentioned in their answers summarized above. These results corroborate suggestions of Goodwin-Jones (2018) for learners to get in contact with the English language and check for pronunciation using sites and apps, recommendations of Braga, Gomes Junior and Racilan (2017) to use apps, other social networks and tasks to enhance language learning and of Delatorre (2017) to improve Brazilian learners of English experience with the language by listening to songs and watching TV series, news, movies and interviews in English, thus improving listening and speaking skills. All in all, by engaging in a digital storytelling task cycle learners may thus foster not only speaking or language-related elements but also other skills as well, such as digital skills specially required to accomplish the task, such as video-editing, for instance (e.g., using the Moviemaker and editing videos was a new real-life task for most learners).

\footnotetext{
${ }^{9}$ To De Bot, Lowie and Verspor's (2007), Ellis' (2007) and Thomson's (2015), it takes into account the cognitive and social aspects of language development; emerges from a real language use (CAMERON; LARSEN-

FREEMAN, 2007; LARSEN-FREEMAN, 2014) and involves variation within and across individuals as well as interaction across lessons and courses and experience with the language (TROFIMOVICH; KENEDY; FOOTE, 2015). According to de Bot, Lowie and Verspoor (2007), Larsen-Freeman (1997, 2014) and Lowie (2011, 2013), the learner's language is a system composed of interdependent into sub-systems, such as phonology, morphology, lexis, semantics, pragmatics, and a change in one of them may cause a change in the others, as pointed out by Larsen-Freeman (1997) and Thomson (2015).
} 
Regarding the use of new tools and strategies in the learning process, participants mentioned that they had contact with English through music or videos, which might indicate that this contact has not been sufficient to enhance their oral production or pronunciation, or even grammar and vocabulary knowledge, as shown in some of their complaints in their answers to the questionnaires. Thus, these results seem to be in agreement with Delatorre's (2017) observation that her participants did not possibly have an effective contact with English through songs, movies or TV shows and series in order to help them to increase the rate of verb intelligibility, which was low and had a moderate correlation with language experience ${ }^{10}$ in the two intelligibility ${ }^{11}$ tests. Despite these results, the use of new tools and strategies, such as technology, images, music and sounds, video clips, text, and/or narration, the digital storytelling components, as suggested by Castañeda (2013), Christiansen and Koelzer (2016), HerreraRamirez (2013), Pardo (2014) and Rahimi and Yadollahi (2017), social networks, as suggested by Namaziandost, Nasri and Keshmirshekan (2019) and Paiva (2019) and smartphones and apps, as suggested by Shorna and Shorna (2019), to teach languages (e.g., English) may result in learners more committed with their own learning since it becomes more contextualized and meaningful (Braga, Gomes Junior \& Racilan, 2017; Shorna \& Shorna, 2019; Tumolo, 2006, 2015, 2017) or just enjoyable as in Shorna and Shorna's (2019) words. In addition, these apparent inconsistent or contradictory results suggest, however, a variation in the language learning process, as proposed by the Dynamic System Theory for language acquisition, which is very common in the language classroom since language learning seems not to be linear and similar to all learners.

Furthermore, their perceptions regarding pronunciation, speaking, training and practicing oral production indicate that they might have not had much time devoted to these topics during their education, which should not be a surprising result since Brazilian schoolcurriculum for elementary and high school formal education ${ }^{12}$ tends to focus more on grammar, reading and writing skills than on skills that tend to be more related to oral production, such as listening and speaking skills and pronunciation in class at the time they probably were enrolled in regular school. This was also observed in Delatorre (2017), who considered that the little attention paid

\footnotetext{
${ }^{10}$ In Delatorre (2017), language experience was measured by participants' answers to questionnaires administered after the two verb intelligibility tests in which they answered about their contact with English language by listening to music, watching TV series, news, movies, playing games or getting in contact with native and non-native speakers of English.

${ }^{11}$ According to Munro and Derwing (1995), intelligibility relates to the extent to which an utterance is understood, and is accessed by the orthographic transcription of all listened words.

${ }^{12}$ It follows the Planos Curriculares Nacionais (1998) and the Orientações Curriculares para o Ensino Médio (2006).
} 
to listening, speaking and pronunciation at school, in contrast to more attention given to reading, writing and grammar, possibly had some influence on the low intelligibility of verbs ending in ed for Brazilian learners of English. Moreover, according to Thomson (2015), the lack of attention to pronunciation may have an impact on grammatical and lexical access and, thus, account for problems in speech production and perception. It may also account for lack of fluency, which, due to the interdependence among language sub-systems advocated by the Dynamic System Theory (See footnote 7), may also help explaining their difficulty with the oral language as a whole, including pronunciation, training and practice as well as with grammar, vocabulary and sentence construction during the digital storytelling task cycle.

According to their answers to the four questionnaires summarized above, participants drew attention to the feedback they received from their teacher and peers regarding grammar and pronunciation, or audio and video-recordings to which they reported as being extremely important and positive. Thus, their answers are in accordance with Braga, Gomes Junior and Racilan (2017), Nishioka (2016) and Yuskel, Robin and McNeil (2011), who considered that digital storytelling may enhance learners' digital skills, critical thinking, interpersonal and collaborative skills, and with Cameron and Larsen-Freeman (2007), who acknowledged that receiving feedback from their teachers and peers may help learners to develop their language.

Taking into account their perceptions about oral production on the digital storytelling task and some considerations on English learning just mentioned, it is possible to point out the necessity to balance in class the use of the four skills of reading, writing, listening and speaking as well as the teaching of some grammar, vocabulary and pronunciation. Such balance could result in a more committed and motivating learning process since it would tend to corroborate their expectations. However, as pointed out by Trevisol (2019), this balanced teaching is not easy to accomplish in class despite some teachers' attempts to achieve it. In addition, as previously discussed, feedback and peer or collaborative work together with technology use and everything available on the internet that they like - which consequently attract their attention, such as songs, videos, TV series, etc - could improve their experience with the language, and thus their language knowledge and speech production in order to be clear and intelligible to all listeners and speakers of English, either native or non-native.

Therefore, the results of present study indicate that the digital storytelling task cycle suggested by the second researcher (e.g., TREVISOL, 2019), the teacher of the participants, was adequate to draw participants' attention to their oral production and language use in class and outside the class, thus corroborating Braga, Gomes Junior and Racilan's (2017), Namaziandost, 
Nasri and Keshmirshekan's (2019) and Shorna and Shorna's (2019) observations that it is the teachers' role to create tasks and assignments adequate to this mobile learning environment that demand a more collaborative work, making students learn with their colleagues, as occurred here. Moreover, as few of the participants mentioned in their answers to the questionnaires that they intend to become teachers of English in the future, results reported in this study lead to another discussion regarding what kind of language, linguistic knowledge and teaching methods should be taught to future Brazilian teachers of English and how it should be done during their education at Brazilian universities mainly.

\section{Conclusion}

This study investigated Brazilian learners of English perceptions about their oral production in a digital storytelling task cycle. In sum, the results demonstrated that participants were concerned about oral production as a whole, including speaking, pronunciation, training and practice, as well as grammar, vocabulary knowledge and sentence construction during the digital story construction process, which is in agreement with the dynamic system theory for language acquisition. In addition, despite the Brazilian curriculum for teaching of foreign languages in regular school, a more balanced teaching, taking into account all these aspects, or as the dynamic system theory defines, sub-systems, just pointed out, could enhance their learning, making them more aware of all of these aspects, more committed and motivated to learn.

Moreover, this study also suggested the great potential and benefit of well designed (and implemented) task cycle for digital storytelling creation - as well as of a task-oriented pedagogical practice in general - since it involved students in the whole process of language learning, thus developing their critical thinking, language awareness and collaborative work. This digital storytelling task cycle also demonstrated the importance of teachers prepared to deal with and propose tasks and technology use in and outside class to develop their students' engagement in the language learning process. Furthermore, these results also revealed that the use of songs, TV series and movies, for instance, seemed not to be enough to help learners improve their oral production despite being able to call their attention to the study of English, sometimes. On the other hand, if the use of technology, as well as songs, videos, movies, TV series and shows and apps were stimulated to be used in and outside class, they could enhance 
leaners' experience with the language and, thus, increase their involvement with it, and consequently, their language learning in order to be clear and intelligible to all speakers of English, either native or non-native. Moreover, feedback provided by the teacher and colleagues as well as peer and collaborative work seem to be very important to raise their awareness regarding oral production and technology use in digital storytelling construction.

Finally, as this study provides data from 14 Brazilian learners of English only, other studies on this topic must be conducted, involving learners from different regions of Brazil, as well as from other countries, and with different proficiency levels in order to check their perceptions regarding L2 oral production in a digital storytelling task cycle. Variation on task cycle duration and other additional tasks could also be included in further studies on this topic.

\section{REFERENCES}

APPEL, C. \& BORGES, F. Task design for L2 oral practice in audioblogs. The EUROCALL Review, 20, 1, In: Proceedings of the Eurocall Conference 2011. University of Nottingham, $31^{\text {st }}$ Augusto $-3^{\text {rd }}$ September, 2011.

BERGSLEITHNER, J. M. Linguagem oral e aspectos cognitivos em linguística aplicada: ensino/aprendizagem de L2/LE através de tarefas. Revista Língua \& Literatura, v. 11, n. 17, p. 113-124, 2009.

BRAGA, J., C., F; GOMES JUNIOR, R., C.; RACILAN, M. Reflexões sobre ensino e aprendizagem de línguas na formação de professores via dispositivos móveis. Hipertextus Revista Digital, v. 16, p. 32-51, 2017.

BYGATE, M. Effects of task repetition on the structure and control of oral language. In Bygate, M.; Skehan, P.; Swain, M. Orgs). Researching pedagogic tasks - second language learning and testing. London: Longman, 2001, p. 23-48.

BYGATE, M.; SKEHAN, P.; SWAIN, M. (Orgs.). Researching pedagogic tasks: Second language learning, teaching and testing, London: Longman, 2001.

CAMERON, L.; LARSEN-FREEMAN, D. Complex systems and applied linguistics. International Journal of Applied Linguistics, v. 17, n. 2, p. 226-239, 2007.

CASTAÑEDA, M. E. "I am proud that I did it and it's a piece of me": Digital storytelling in the foreign language classroom. CALICO Journal, v. 30, n. 1, p. 44-62, 2013.

CHRISTIANSEN, M. S.; KOELZER, M. L. Digital storytelling: using different technologies for EFL. MEXTOL Journal, v. 40, n. 1, p. 1-14, 2016.

DE BOT, K.; LOWIE, W.; VERSPOOR, M. A dynamic system approach to second language acquisition. Bilingualism: Language and Cognition, v. 10, n. 1, p. 7-21, 2007. 
DELATORRE, F. Intelligibility of English verbs ending in -ed for Brazilian learners of English as listeners. 2017. 312 f. Tese (Doutorado em Letras - Inglês: Estudos Linguísticos e Literários) - Centro de Comunicação e Expressão, Universidade Federal de Santa Catarina, Florianópolis, 2017.

D'ELY, R. C. F. A focus on learners' metacognitive processes: the impact of strategic planning, repetition, strategic planning plus repetition, and strategic planning for repetition on L2 oral performance. 2006. 373 f. Tese (Doutorado em Letras/Inglês e Literatura Correspondente) - Centro de Comunicação e Expressão, Universidade Federal de Santa Catarina, Florianópolis, 2006.

DONG, Y. Critical thinking in second language writing: concept, theory and pedagogy. 2015. 242 f. Tese (Doctor of Philosophy) - University of British Columbia, Vancouver, 2015.

ELLIS, N. C. Dynamic systems and SLA: The woods and the trees. Bilingualism: Language and Cognition, v. 10, n. 1, p. 23-25, 2007.

ELLIS, R. (Org). Task-based language learning and teaching. Oxford: Oxford University Press, 2003.

GONZÁLEZ-LLORET, M.; ORTEGA, L. (Orgs.). Technology-mediated TBLT: researching technology and tasks. Amsterdam: John Benjamins, 2014.

HERRERA RAMÍREZ, Y. E. Writing skill enhancement when creating narrative texts through the use of collaborative writing and the Storybird Web 2.0 tool. Colombian Applied Linguistics Journal, v. 15, n. 2, p. 166-183, 2013.

LARSEN-FREEMAN, D. Chaos/complexity science and second language acquisition. Applied Linguistics, v. 18, n. 2, p. 141-165, 1997.

LARSEN-FREEMAN, D.. Saying what you mean: Making a case for 'language acquisition' to become 'language development'. Language Teaching, p. 1-15, 2014.

LOWIE, W. M. Early L2 Phonology: a dynamic approach. In WREMBEL, M.; KUHL, M.; DZIUBALSKA-KOŁACZYK, K. (Orgs.), Achievements and Perspectives in SLA of Speech: New Sounds 2010, 2011. Peter Lang Publishing Group, 2011, p. 159-170.

LOWIE, W. Dynamic systems theory approaches to second language acquisition. In CHAPPELlE, C. A. (Org.) The encyclopedia of Applied Linguistics. Oxford: Blackwell, 2013, p. $1-9$.

MUNRO, M. J.; DERWING, T. M. Processing time, accent, and comprehensibility in the perception of native and foreign-accented speech. Language \& Speech, v. 38, p. 289-306, 1995.

NAMAZIANDOST, E.; NASRI , M.; KESHMIRSHEKAN, M., H. Teachers' and Learners' Perceptions toward Using Social Media for Developing Oral Proficiency. Journal of Language Teaching and Research, v. 10, n. 6, p. 1341-1350, 2019. 
NISHIOKA, H. Analysing language development in a collaborative digital storytelling project: Sociocultural perspectives. System, v. 62, p. 39-52, 2016. .ORIENTAÇÕES CURRICULARES PARA O ENSINO MÉDIO. Secretaria de Educação Básica, Ministério da Educação, Brasília, DF. 2006. Disponível em http://portal.mec.gov.br/seb/arquivos/pdf/book_volume_01_internet.pdf_Acessado em $10 \mathrm{de}$ Out. de 2017.

PAIVA, V. L. M. O. Tecnologias Digitais no Ensino de Línguas: Passado, presente e futuro. Revista da ABRALIN, v. XVIII, n. 1, p. 2-26, 2019.

PARÂMETROS CURRICULARES NACIONAIS (PCNs) Secretaria de Educação Fundamental, Ministério da Educação, Brasília, DF. 1997. Disponível em http://portal.mec.gov.br/seb/arquivos/pdf/livro01.pdf on Acessado em 10 de Out. de 2017.

PARDO, B. S.. Digital Storytelling: A case study of the creation, and narration of a story by EFL Learners. Digital Education Review, v. 26, p. 74-84, 2014.

RAHIMI, M.; YADOLLAHI, S. Effects of offline vs. online digital storytelling on the development of EFL learners' literacy skills. Cogent Education, v. 4, p. 1-13, 2017.

SANTOS, M. F.; TREVISOL, J. R.; DELATORRE, F. Título do Artigo. In. TREVISOL, J. R.; SILVA, I. T. (Orgs), Fundamentos e Práticas no Ensino de Línguas Estrangeiras. Alagoinhas: Editora Bordô-Grená, in press.

SCHAEFER, R.; SALBEGO, N.; LORENSET, C.; C. Foreign language learning development: Reflections on the contribution of digital technology. Revista de Letras Norte@mentos, v. 12, n. 19, p. 143-157, 2019.

SHORNA, S., A.; SHORNA, I., J. Use of Mobile Apps to Improve English Language Skills Outside the Bangladeshi University Classrooms. Journal of Humanities and Social Science, v. 24 n. 12, p. 17-21, 2019.

SWAIN, M. Three functions of output in second language learning. In: COOK, G.; SEIDHOFER, B. (Orgs.) Principles and practice in applied linguistics. Oxford: Oxford University Press, 1995.

THOMSON, R., J. Fluency. In. REED, M.; LEVIS, J. M. (Orgs). The handbook of English pronunciation. West Sussex: Wiley Blackwell, 2015, p. 209-226.

TREVISOL, J., R. Investigating 12 learners' oral production and perception of a cycle of tasks with digital storytelling: An exploratory study in technology-mediated TBLT. 2019. 361 f. Tese (Doutorado em Letras - Inglês: Estudos Linguísticos e Literários) - Centro de Comunicação e Expressão, Universidade Federal de Santa Catarina, Florianópolis,

TROFIMOVICH, P.; KENEDY, S.; FOOTE, J., A. Variables affecting L2 pronunciation Development: In. REED, M.; LEVIS, J. M. (Orgs). The handbook of English pronunciation. West Sussex: Wiley Blackwell, 2015, p. 353-373. 
TUMOLO, C. H. S.. Ensino à distância: horizontes para o ensino de línguas estrangeiras. Fragmentos, v. 30, p. 25-34, 2006.

TUMOLO, C. H. S. Histórias digitais como recurso para ensino/aprendizagem de Inglês como língua estrangeira. Revista Estudos Anglo Americanos, v. 43, p. 100-117, 2015.

TUMOLO, C. H. S. Recursos digitais para o ensino/aprendizagem de inglês como língua estrangeira: o vídeo como destaque. In: TOMITCH, L. M. B.; HEBERLE, V. M. (Orgs.), Perspectivas atuais de aprendizagem e ensino de línguas. Florianópolis: LLE/CCE/UFSC, 2017, p. 51-775.

WEISSHEIMER, J. Working memory capacity and the development of L2 speech production. 2007. Tese (Doutorado em Letras/Inglês e Literatura Correspondente) - Centro de Comunicação e Expressão, Universidade Federal de Santa Catarina, Florianópolis, 2007.

YUSKEL, P.; ROBIN, B.; MCNEIL, S. Educational Uses of Digital Storytelling all around the World. In KOEHLER, M.; MISHRA, P. (Orgs.), Proceedings of Society for Information Technology \& Teacher Education International Conference 2011, 2011. Chesapeake, VA: Association for the Advancement of Computing in Education (AACE), 2011, p. 1264-1271.

Recebido em 28/02/2020. Aceito em 13/06/2020. 